\title{
IMPLEMENTASI TUGAS KEPALA DESA DALAM PEMBANGUNAN BERDASARKAN UNDANG-UNDANG NOMOR 6 TAHUN 2014 TENTANG DESA
}

\author{
Jhony Fredy Hahury \\ Fakultas Ilmu Sosial dan Ilmu Politik Universitas Kapuas \\ email :jf28hahury@gmail.com
}

\begin{abstract}
Abstrak : implementasi tugas kepala desa dalam pembangunan berdasarkan Undang-Undang Nomor 6 tahun 2014 tentang Desa dalam pembangunan di Desa Binjai Hilir Kecamatan Binjai Hulu Kabupaten Sintang merupakan suatu kewajiban yang dilaksanakan mengingat salah satu tugas kepala desa adalah pelaksanaan pembangunan desa.Penelitian ini bertujuan untuk mengetahui dan mendeskripsikan tentang implementasi fungsi kepala desa dalam pembangunan.Dalam penelitian ini diketahui bahwa dalam pelaksanaan tugas kepala desa, ada beberapa faktor yang menjadi penghambat seperti komunikasi yang belum maksimal dilaksanakan dengan lembaga desa, BPD dan masyarakat serta masih kurangnya partisipasi masyarakat dalam pembangunan desa. Sedangkan yang menjadi faktor penunjang adalah keterlibatan aktif aparatur desa dalam pelaksanaan program-program pembangunan desa.
\end{abstract}

Kata Kunci :Implementasi, Tugas Kepala Desa, Pembangunan.

Undang-Undang Nomor 6 Tahun 2014 tentang Desa yang didukung dengan dengan Peraturan Pemerintah Nomor 43 Tahun 2014 tentang Peraturan Pelaksanaan Undang-Undang Nomor 6 Tahun 2014 tentang Desa merupakan sebuah isntrumen kebijakan formal pembangunan bangsa yang meletakan desa sebagai sebuah komunitas masyarakat Indonesia yang perlu di berdayakan guna mencapai kemandirian bangsa yang berdaya saing tinggi. Keberhasilan pembangunan nasional di berbagai sektor terutama kemajuan pembangunan daerah sampai pada tingkat pedesaan yang merupakan mata rantai dalam sistem pembangunan nasional. Hal ini mengacu kepada prinsip pembangunan yang lebih partisipatif sehingga akan mempertegas kembali visi dan misi dari pembangunan manusia yang seutuhnya. Oleh karena itu, eksistensi desa perlu ditegaskan dalam rangka memperkuat hak-hak desa dengan bersandar kepada kearifan lokal masyarakat sehingga akan mewujudkan masyarakat desa yang maju, mandiri, dan sejahtera.

Keberhasilan pembangunan nasionaltidak terlepas dari pembangunan pedesaan karena mencerminkan percepatan pembangunan dengan mengacu kepada prinsip keadilan dan pemerataan. Oleh karena itu, dengan berlakunya UndangUndang Nomor 6 Tahun 2014 tentang Desa tentunya sebagai upaya mewujudkan pembangunan yang partisipatif serta perencanaan pembangunan desa yang partisipatif sehingga pembangunan desa dapat berjalan dengan lancar dan mampu meningkatkan kemandirian masyarakat di tingkat lokal.

Pembangunan nasional di mulai dari pembangunan pedesaan dengan pendekatan partisipatif masyarakat desa karena desa menjadi salah satu indikator keberhasilan pembangunan nasional. Sebagaimana pendapat Marbun (2000:34) yang menyatakan bahwa faktor desa perlu digarap dan dikembangkan secara maksimal karena tidak berlebihan kalau disebut pembangunan di Indonesia tidak ada artinya tanpa pembangunan desa. Ketahanan nasional juga berada di desa, hari depan Indonesia terletak dan tergantung dari keberhasilan pembangunan desa. Hal ini berarti bahwa kegagalan pembangunan di tingkat pedesaan juga merupakan kegagalan pembangunan di tingkat nasional, karena belum terjadinya pendistribusian pembangunan secara merata di daerah Indonesia. Berdasarkan Undang-Undang Nomor 6 Tahun 2016 tentang Desa disebutkan bahwa "Desa atau yang disebut dengan nama lain, selanjutnya disebut desa adalah kesatuan masyarakat hukum yang berwenang untuk mengatur dan mengurus kepentingan masyarakat setempat, berdasarkan 
asal-usul dan adat istiadat setempat yang diakui dan dihormati dalam sistem pemerintahan Negara kesatuan Republik Indonesia”. Kepala desa mempunyai tugas menyelenggarakan urusan pemerintahan, pembangunan dan kemasyarakatan serta tugas-tugas lain yang dilimpahkan kepada desa.Fungsi kepala desa selakupimpinan pemerintahan harus dilaksanakan secara optimal baik serta aspirasi-aspirasi yang disampaikan oleh masyarakat harus didengar dan tindak lanjuti oleh seorang kepala desa agar apa yang menjadi tujuan bersama bisa tercapai sesuai dengan yang diharapkan oleh masyarakat.

Dengan demikian, pelaksanaan pembangunan desa harus lebih diprioritaskan serta perlu mendapat dukungan dari semua pihak baik dari perangkat desa, Badan Permusyawaratan Desa (BPD) maupun organisasi masyarakat setempat agar pelaksanaan pembangunan desa lebih maksimal. Pelaksanaan pembangunan merupakan proses keberlangsungan kehidupan masyarakat desa. Sebagai proses perubahan sosial secara berencana dengan meliputi berbagai dimensi kemajuan dalam rangka kesejahteraan ekonomi, modernisasi, kemajuan bangsa, wawasan lingkungan bahkan peningkatan kualitas manusia. Implementasi tugas kepala desa dalam pembangunan desa pada prinsipnya diharapkan dapat mencerminkan kebutuhan masyarakat desa. Implementasi dari kebijakan ini juga sebagaimana yang dilakukan oleh kepala desa Binjai Hilir Kecamatan Binjai Hulu Kabupaten Sintang. Implementasi tugas dan kewenangan kepala desa Binjai Hilir berdasarkan Undang-Undang nomor 6 tahun 2014 tentang Desa sudah dilaksanakan namun belum maksimal dikarenakan ada beberapa faktor yang menjadi penghambat dalam implementasi tugas kepala desa dalam pembangunan yakni masalah koordinasi, sumberdaya manusia perangkat desa serta partisipasi masyarakat yang kurang terlibat dalam pembangunan desa. Berangkat dari pemaparan latar belakang di atas terkait implementasi tugas kepala desa berdasarkan Undang-Undang Nomor 6 tahun 2014 tentang Desa, maka penulis tertarik untuk melakukan penelitian yang berhubungan dengan implementasi sehingga judul yang diangkat adalah "implementasi tugas kepala desa dalam pembangunan berdasarkan Undang-Undang Nomor 6 tahun 2014 tentang Desa di Desa Binjai Hilir Kecamatan Binjai Hulu Kabupaten Sintang”. Implementasi Undang-Undang Nomor 6 tahun 2014 tentang Desa merupakan sebuah instrumen kebijakan formal pembangunan bangsa yang meletakan desa sebagai sebuah komunitas masyarakat Indonesia yang mesti diberdayakan guna mencapai kemandirian dan kesejateraan masyarakat.Undang-Undang tersebut merupakan sebuah ruang kebijakan yang memberikan otoritas kepada desa untuk mengeksplorasi potensi lokalnya untuk pembangunan masyarakat baik secara pribadi maupun kolektif. Oleh karena itu, menurut UndangUndang Nomor 6 Tahun 2014 tentang Desa Pasal 18 tentang kewenangan desa meliputi kewenangan di bidang penyelenggaraan pemerintahan desa, pelaksanaan pembangunan desa, pembinaan kemasyarakatan desa, dan pemberdayaan masyarakat desa berdasarkan prakarsa masyarakat, hak asal usul, dan adat istiadat desa. Dengan demikian, implementasi Undang-Undang desa ini sebagai intisari dari spirit pembangunan desa yang diharapkan akan mendorong perubahan desa agar menuju kemandirian sesuai dengan visi dan misi pembangunan desa mandiri, maju, partisipatif dan sejahtera.

Berkaitan dengan hal di atas, maka tujuan pemerintahan dapat terwujud apabila kebijakan di implementasikan dengan baik sebagaimana dijelaskan oleh Mazmanian dan Sabatier dalam Wahab (2001:65), mengatakan bahwa implementasi kebijakan pemerintahan mengandung makna tertentu, yaitu : memahami apa yang senyatanya terjadi sesudah suatu program dinyatakan berlaku atau dirumuskan merupakan fokus perhatian implementasi kebijaksanaan, yakni kejadian-kejadian dan kegiatan-kegiatan yang timbul sesudah disahkannya pedoman-pedoman kebijaksanaan negara, yang mencakup baik usahausaha untuk mengadministrasikannya maupun untuk menimbulkan akibat/dampak nyata pada masyarakat atau kejadian-kejadian. Oleh karena itu, setiap kebijakan publik harus di 
implementasikan, sebagaimana ditegaskan oleh Van Meter dan Van Horn dalam Winarno (2005:102) bahwa implementasi kebijakan publik sebagai berikut: "tindakan-tindakan yang dilakukan oleh organisasi publik yang diarahkan untuk mencapai tujuan-tujuan yang telah ditetapkan dalam keputusan-keputusan sebelumnya". Tindakantindakan ini mencakup usaha-usaha untuk mengubah keputusan-keputusan menjadi tindakantindakan operasional dalam kurun waktu tertentu maupun dalam rangka melanjutkan usah-usaha untuk mencapai perubahan-perubahan besar dan kecil yang ditetapkan oleh keputusan-keputusan kebijakan". Sedangkan Grindle dalam Tachjan (2006) bahwa implementasi merupakan proses umum tindakan administratif yang dapat diteliti pada tingkat program tertentu. Masih menurutnya bahwa proses implementasi baru akan dimulai apabila tujuan dan sasaran telah ditetapkan, program kegiatan telah tersusun dan dana telah siap dan telah disalurkan untuk mencapai sasaran.

Dengan demikian, implementasi kebijakan sebagai proses kegiatan administratif yang dilakukan setelah kebijakan ditetapkan atau disetujui. Sehingga fungsi dan tujuan implementasi ialahuntuk membentuk suatu hubungan yang memungkinkan tujuan-tujuan ataupun sasaransasaran kebijakan publik (politik) dapat diwujudkan sebagai "outcome" (hasil akhir) dari kegiatan yang dilakukan oleh pemerintah (Tachjan, 2006:26). Berdasarkan beberapa definisi yang disampaikan para ahli di atas, disimpulkan bahwa implementasi merupakan suatu kegiatan atau usaha yang dilakukan oleh pelaksana kebijakan dengan harapan akan memperoleh suatu hasil yang sesuai dengan tujuan atau sasaran dari suatu kebijakan itu sendiri. Hakikat utama implementasi kebijakan adalah memahami apa yang seharusnya terjadi sesudah suatu program dinyatakan berlaku atau dirumuskan. Pemahaman tersebut mencakup usaha-usaha untuk mengadministrasikannya dan menimbulkan dampak nyata pada masyarakat atau kejadian-kejadian (Widodo, 2010:87).

Implementasi kebijakan juga tidak terlepas dari beberapa model yang menjadi sukses tidaknya suatu kebijakan. Model implementasi kebijakan menurut pandangan Edwards III (1980) dalam Ekowati (2008) dipengaruhi empat variabel, yakni; (1) komunikasi, (2) sumberdaya, (3) disposisi dan kemudian (4) struktur birokrasi. Keempat variabel tersebut juga saling berhubungan satu sama lain. Keempat variable tersebut dijelaskan sebagai berikut : Komunikasi. Implemetasi kebijakan publik agar dapat mencapai keberhasilan, mensyaratkan agar implementor mengetahui apa yang harus dilakukan secara jelas. Oleh karena itu diperlukan adanya tiga hal, yaitu; (1) penyaluran (transmisi) yang baik akan menghasilkan implementasi yang baik pula (kejelasan); (2) adanya kejelasan yang diterima oleh pelaksana kebijakan sehingga tidak membingungkan dalam pelaksanaan kebijakan, dan (3) adanya konsistensi yang diberikan dalam pelaksanaan kebijakan. Jika yang dikomunikasikan berubah-ubah akan membingungkan dalam pelaksanaan kebijakan yang bersangkutan. Sumberdaya. Tanpa sumberdaya, kebijakan hanya tinggal di kertas menjadi dokumen saja tidak diwujudkan untuk memberikan pemecahan masalah yang ada di masyarakat dan upaya memberikan pelayan pada masyarakat. Sumberdaya tersebut dapat berwujud sumberdaya manusia, yakni kompetensi implementor dan sumberdaya finansial. Disposisi. Suatu disposisi dalam implementasi dan karakteristik, sikap yang dimiliki oleh implementor kebijakan, seperti komitmen, kejujuran, komunikatif, cerdik dan sifat demokratis. Implementor baik harus memiliki disposisi yang baik, maka dia akan dapat menjalankan kebijakan dengan baik seperti apa yang diinginkan dan ditetapkan oleh pembuat kebijakan. Struktur birokrasi. Organisasi, menyediakan peta sederhana untuk menunjukkan secara umum kegiatan-kegiatannya dan jarak dari puncak menunjukkan status relatifnya. Salah satu dari aspek struktur organisasi adalah adanya prosedur operasi yang standar (standard operating procedures/SOP). Fungsi dari SOP menjadi pedoman bagi setiap implementor dalam bertindak. Struktur organisasi yang terlalu panjang akan cenderung melemahkan pengawasan dan menimbulkan red-tape, yakni birokrasi yang rumit dan kompleks. 
Hal demikian pada gilirannya menyebabkan aktivitas organisasi tidak fleksibel.

Berkaitan dengan implementasi tugas kepala desa dalam pembangunan. Hal ini sebagaimana dikatakan oleh Tjokroamidjojo (2001:113) bahwa "pembangunan merupakan suatu proses pembaharuan yang kontinu dan terus menerus dari suatu keadaan tertentu kepada suatu keadaan yang lebih baik". Berdasarkan konsep pemikiran tersebut, maka Todaro dalam Ngusmanto (2015:27) menegaskan bahwa konsep pembangunan secara luas sebagai suatu proses perbaikan yang berkesinambungan atas suatu masyarakat atau sistem sosial secara keseluruhan menuju kehidupan yang lebih baik atau lebih manusiawi. Oleh karena itu, pembangunan pada dasarnya merupakan suatu usaha perubahan untuk mengembangkan diri pada suatu keadaan dari sifat tradisional menuju kearah yang lebih baik dalam rangka meningkatkan kualitas hidup masyarakat. Implementasi tugas kepala desa merupakan sesuatu hal yang tidak bisa dipungkiri bahwa tugas dan tanggungjawab dari seorang kepala desa sangat berat yang tentunya kepala desa harus memiliki kemampuan manajemen kepemimpinan yang baik agar mampu mempengaruhi masyarakat guna pelaksanaan program-program pembangunan desa. Hal ini menurutUndang-Undang Desa No 6 Tahun 2014 tentang Desa, dalam pasal 1 angka 3 disebutkan bahwa "kepala desa adalah pemerintah desa atau yang disebut dengan nama lain yang dibantu perangkat desa sebagai unsur penyelenggara pemerintahan desa". Adapun tugas kepala desa disebutkan dalam pasal 26 ayat (1) yaitu menyelenggarakan pemerintahan desa, melaksanakan pembangunan desa, pembinaan kemasyarakatan desa dan pemberdayaan masyarakat".

Sedangkan dalam melaksanakan tugas sebagaimana pasal 26 ayat (2), Kepala Desa berwenang, yakni : Memimpin penyelenggaraan Pemerintahan Desa;Mengangkat dan memberhentikan perangkat Desa; Memegang kekuasaan pengelolaan Keuangan dan Aset Desa;Menetapkan Peraturan Desa;Menetapkan Anggaran Pendapatan dan Belanja Desa;Membina kehidupan masyarakat Desa;Membina ketenteraman dan ketertiban masyarakat Desa;Membina dan meningkatkan perekonomian Desa serta mengintegrasikannya agar mencapai perekonomian skala produktif untuk sebesarbesarnya kemakmuran masyarakat Desa;Mengembangkan sumber pendapatan Desa; Mengusulkan dan menerima pelimpahan sebagian kekayaan negara guna meningkatkan kesejahteraan masyarakat Desa; Mengembangkan kehidupan sosial budaya masyarakat Desa; Memanfaatkan teknologi tepat guna; Mengoordinasikan Pembangunan Desa secara partisipatif; Mewakili Desa di dalam dan di luar pengadilan atau menunjuk kuasa hukum untuk mewakilinya sesuai dengan ketentuan peraturan perundang-undangan; dan Melaksanakan wewenang lain yang sesuai dengan ketentuan peraturan perundang-undangan.

Sementara dalam melaksanakan tugas sebagaimana dimaksud pada pasal 26 ayat (3), Kepala Desa berhak: Mengusulkan struktur organisasi dan tata kerja Pemerintah Desa; Mengajukan rancangan dan menetapkan Peraturan Desa; Menerima penghasilan tetap setiap bulan, tunjangan, dan penerimaan lainnya yang sah, serta mendapat jaminan kesehatan; Mendapatkan pelindungan hukum atas kebijakan yang dilaksanakan; dan Memberikan mandat pelaksanaan tugas dan kewajiban lainnya kepada perangkat Desa. Sedangkan dalam melaksanakan tugas, kewenangan, hak, dan kewajiban maka sebagaimana pasal 27 Kepala Desa wajib: Menyampaikan laporan penyelenggaraan Pemerintahan Desa setiap akhir tahun anggaran kepada Bupati/Walikota; Menyampaikan laporan penyelenggaraan Pemerintahan Desa pada akhir masa jabatan kepada Bupati/Walikota; Memberikan laporan keterangan penyelenggaraan pemerintahan secara tertulis kepada Badan Permusyawaratan Desa setiap akhir tahun anggaran; dan Memberikan dan/atau menyebarkan informasi penyelenggaraan pemerintahan secara tertulis kepada masyarakat Desa setiap akhir tahun anggaran. Berdasarkan penjelasan pasal di atas, maka tugas kepala desa merupakan suatu kewajiban yang dilaksanakan sesuai dengan 
peraturan yang berlaku. Di sisi lain tugas kepala desa adalah bagaimana menyelenggarakan pelayanan publik yang baik bagi masyarakat dan membuka akses serta menggerakkan perekonomian masyarakat sehingga pembangunan desa lebih maju, mandiri dan sejahtera.

Spirit pembangunan desa dengan mengacu kepada pendekatan partisipatif serta komunikasiyang efektif dalam menentukan arah pembangunan desa dengan memberdayakan sumber-sumber yang ada. Komunikasi berperan penting dalam pembangunan, dalam pengertian yang sempit, komunikasi pembangunan merupakan segala upaya dan cara, serta teknik penyampaian gagasan, dan keterampilan-keterampilan pembangunan yang berasal dari pihak yang memprakarsai pembangunan dan ditujukan kepada masyarakat luas, dengan tujuan agar masyarakat memahami, menerima, dan berpartisipasi dalam melaksanakan gagasan-gagasan yang disampaikan. Sedangkan dalam arti yang luas, komunikasi pembangunann meliputi peran dan fungsi komunikasi (sebagai suatu aktivitas pertukaran pesan secara timbal balik) di antara semua pihak yang terlibat dalam usaha pembangunan, terutama antara masyarakat dengan pemerintah, sejak dari proses perencanaan, pelaksanaan, dan penilaian terhadap pembangunan (Nasution, 1996:92).

Oleh karena itu, melalui komunikasi yang baik antara pemerintah dan masyarakat, maka pembangunan yang direncanakan akan memberikan manfaat dalam meningkatkan kesejahteraan masyarakat.Sehingga Komunikasi pembangunan mempunyai tujuan, antara lain memberikan informasi, persuasif (menggugah perasaan), mengubah perilaku, mengubah pendapat atau opini, mewujudkan partisipasi masyarakat, dan meningkatkan pendapatan. Tujuan-tujuan komunikasi pembangunan ini diharapkan dapat menyebabkan perubahan di masyarakat atau perubahan sosial (social change). Oleh karena itu, komunikasi dan partisipasi sebagai salah satu kunci utama untuk menyelaraskan berbagai pelaksanaan kegiatan pembangunan agar tidak terjadi kekacauan maupun kesalahan dengan jalan menghubungkan, menyatukan dan menyelaraskan kegiatan pembangunan mulai dari tingkat bawah sampai pada tingkat atas, sehingga terdapat kerjasama yang terarah dalam usaha mencapai tujuan pelaksanaan pembangunan.

Tugas seorang kepala desa tentunya perlu ditunjang dengan sumber daya manusia (SDM) dalam suatu organisasi sebagai modal utama dalam rangka pelaksanaan pembangunan di desa. Sebagaimana dijelaskan oleh Haris (2000:4) bahwa "sumber daya manusia (SDM) adalah faktor sentral dalam suatu organisasi. Apapun bentuk serta tujuannya, organisasi dibuat berdasarkan berbagai visi untuk kepentingan manusia dan dalam pelaksanaan misinya dikelola dan diurus oleh manusia. Jadi, manusia merupakan faktor strategis dalam semua kegiatan institusi/organisasi". Dengan demikian, maka sumber daya manusiayang dibangun atau dikembangkan melalui proses pembangunan yang matang sehingga terwujud manusia yang berkualitas sesuai dengan hakikat dan sasaran pembangunan nasional Indonesia. Penyelenggaraan pembangunan desa selalin sumberdaya manusia yang berkualitas perlu ada dukungan melalui partisipasi masyarakat sebagai manifestasi dari proses perencanaan pembangunan. Dengan demikian, partisipasi masyarakat perlu dibina dan terus ditingkatkan agar pembangunan desa mencapai sasaran yang diharapkan. Sebagaimana dijelaskan Tjokroamidjojo (1998:24) bahwa "partisipasi dalam pembangunan merupakan upaya yang penting, karena akan menghasilkan pembangunan yang sangat memuaskan".

Partisipasi masyarakat dalam pembangunan bisa berjalan efektif dan berhasil dengan baik apabila masyarakat tersebut terlibat langsung dalam seluruh proses kegiatan yaitu : (1) Partisipasi masyarakat dalam perencanaan, (2) Partisipasi masyarakat dalam pelaksanaan, (3) Partisipasi masyarakat dalam pemanfaatan dan pemeliharaan hasil, (4) Partisipasi masyarakat dalam pengawasan dan evaluasi, (5) Partisipasi masyarakat dalam pemanfaatan peluang kegiatan usaha. Partisipasi diartikan sebagai keikutsertaan seseorang secara sukarela tanpa dipaksa sebagaimana yang dijelaskan Sastropoetro dalam Lugiarti (2004:7) bahwa partisipasi adalah 
keterlibatan secara spontan dengan kesadaran disertai tanggung jawab terhadap kepentingan kelompok untuk mencapai tujuan. Selanjutnya dijelaskan oleh Wibisono (1989:41) "partisipasi masyarakat sering diartikan sebagai keikutsertaan, keterlibatan dan kebersamaan anggota masyarakat dalam suatu kegiatan tertentu, baik secara langsung maupun tidak langsung, sejak dari gagasan, perumusan kebijaksanaan hingga pelaksanan program". Partisipasi secara langsung berarti anggota masyarakat tersebut ikut memberikan bantuan tenaga dalam kegiatan yang dilaksanakan. Sedangkan partisipasi tidak langsung berupa keuangan, pemikiran dan material yang diperlukan.

Berdasarkan pengertian di atas maka dapat disimpulkan bahwa partisipasi merupakan keikutsertaan masyarakat dalam pelaksanaan suatu kegiatan dimulai dari tingkat paling awal yaitu perencanaan hingga kegiatan tersebut selesai dan pemanfaatannya dirasakan bersama sama oleh masyarakat. Partisipasi sendiri tidak terbatas pada kegiatan fisik atau pemberian dana namun juga menjaga mengelola dan mempertahankan apa yang sudah masyarakat capai dari suatu kegiatan yang diselenggarakan. Berdasarkan pendapat ahli di atas, maka faktor yang sangat penting diinginkan adalah partisipasi aktif masyarakat dalam setiap kegiatan pembangunan yaitu turut serta mengambil bagian dalam kegiatan perencanaan, pelaksanaan, pengawasan dan tanggung jawab atas hasil-hasil pembangunan yang telah dicapai.Partisipasi masyarakat dalam pelaksanaan pembangunan desa juga tidak terlepas dari beberapa prinsip dasar sebagai cara yang dilakukan oleh masyarakat. Hal ini sebagaimana dijelaskan oleh Marzali (2003:17) bahwa tiga prinsip dasar dalam menumbuhkan partisipasi masyarakat desa agar ikut serta dalam pembangunan dapat dilakukan dengan cara: Learning process (learning by doing); proses kegiatan dengan melakukan aktivitas proyek dan sekaligus mengamati, menganalisa kebutuhan dan keinginan masyarakat. Institusional development; melakukan kegiatan melalui pengembangan pranata sosial yang sudah ada dalam masyarakat. Karena institusi atau pranata sosial masyarakat merupakan daya tamping dan daya dukung sosial.
Participatory; cara ini merupakan suatu pendekatan yang umum dilakukan untuk dapat menggali needs yang ada dalam masyarakat.

Bentuk partisipasi masyarakat dalam tahap pembangunan ada dalam beberapa bentuk. Sebagaimana Slamet (2003:89) bentuk partisipasi masyarakat dalam pembangunan terbagi atas tiga tahap, yaitu: Partisipasi didalam tahap perencanaan Partisipasi di dalam tahap perencanaan (idea planing stage). Partisipasi pada tahap ini maksudnya adalah pelibatan seseorang pada tahap penyusunan rencana dan strategi dalam penyusunan kepanitian dan anggaran pada suatu kegiatan/proyek. Masyarakat berpartisipasi dengan memberikan usulan, saran dan kritik melalui pertemuan-pertemuan yang diadakan Partisipasi dalam tahap pelaksanaan Partisipasi pada tahap ini maksudnya adalah pelibatan seseorang pada tahap pelaksanaan pekerjaan suatu proyek. Masyarakat disini dapat memberikan tenaga, uang ataupun material/barang serta ide-ide sebagai salah satu wujud partisipasinya pada pekerjaan tersebut. Partisipasi didalam tahap pemanfaatan Partisipasi pada tahap ini maksudnya adalah pelibatan seseorang pada tahap pemanfaatan suatu proyeksetelah proyek tersebut selesai dikerjakan. Partisipasi masyarakat pada tahap ini berupa tenaga dan uang untuk mengoperasikan dan memelihara proyek yang telah dibangun.

\section{METODE PENELITIAN}

Penelitian ini dilaksanakan di Desa Binjai Hilir Kecamatan Binjai Hulu Kabupaten Sintang. Jenis penelitian ini menggunakan penelitian deskriptif kualitatif. Subjek atau informan adalah orang yang memberi informasi tentang data yang diinginkan peneliti berkaitan dengan penelitian yang sedang dilaksanakannya. Oleh karena itu, subjek dalam penelitian ini terdiri dari Kepala Desa, Sekretaris Desa, Kepala Urusan Pembangunan, Ketua BPD dan Tokoh adat. Pengumpulan data melalui wawancara mendalam, teknik observasi dan teknik dokumentasi. Teknik analisis data yang digunakan adalah analisis data kualitatif dengan model analisis data dari Miles dan Huberman (1992) yaitu model analisis interaktif. Dalam model ini 
terdapat tiga komponen analisis yaitu : reduksi data, penyajian data dan penarikan kesimpulan.

\section{HASIL PENELITIAN DAN PEMBAHASAN}

Implementasi tugas kepala desa sebagai kewajiban kepala desa dalam melaksanakan penyelenggaraan pemerintahan desa, pemberdayaan masyarakat, dan pelaksanaan pembangunan desa. Pelaksanaan tugas kepala desa merupakan upaya yang harus dilaksanakan sesuai dengan Undang-Undang Nomor 6 Tahun 2014 tentang Desa mempertegas bahwa tugas dan tanggung jawab kepala desa merupakan peran penting dalam menjalankan penyelenggaraan pemerintahan dan pembangunan. Implementasi dari tugas kepala desa ini tidak lain adalah untuk melaksanakan tugas dan fungsi sebagai kepala desa serta sebagai kepala pemerintahan dengan baik sehingga membawa perubahan bagi kepentingan dan kebutuhan masyarakat desa.

Tugas dan tanggung kepala desa tentunya dalammelaksanakan tugas-tugas pemerintahan maupun program-program pembangunan desa sesuai dengan peraturan yang berlaku.Dengan adanya undang-undang desa ini maka tugas kepala desa lebih fokus pada pelaksanaan pembangunan desa yang lebih partisipatif dimana bagaimana melibatkan masyarakat dalam perencanaan sampai pada monitoring pelaksanaan program-program pembangunan desa yang dilaksanakan. Oleh karena itu, dalam melaksanakan tugasnya diperlukan dukungan dari semua aparatur pemerintahan desa maupun lembaga desa dalam rangka kerjasama untuk kemajuan pembangunan desa kedepannya. Implementasi tugas kepala desa menurut Undang-Undang Nomor 6 Tahun 2014 tentang Desa, merupakan dasar dalam pelaksanaan pemerintahan desa, pelaksanaan pembangunan dan pemberdayaan masyarakat. Implementasi tugas kepala desa sangat penting dilaksanakan sesuai dengan undang-undang desa. Menurut hasil wawancara dengan Ketua BPD dikatakan bahwa BPD tetap konsisten berkomunikasi dan bekerjasama dengan pemerintahan desa dalam upaya membantu melaksanakan program-program desa serta mengajak masyarakat untuk bersamasama berpartisipasi dalam rangka keterlibatan aktif pembangunan desa sehingga akan menciptakan pembangunan desa yang tumbuh dengan semangat kekeluargaan dan gotong royong.

Implementasi tugas kepala desa dalam pelaksanaan pembangunan desa tentunya membutuhkan peran komunikasi dan kerjasama dari semua pihak. Menurut hasil wawancara dengan Kepala Desa dikatakan bahwa komunikasi sebagai faktor penting dalam menunjang tugas kepala desa karena tanpa komunikasi serta kerjasama dengan berbabagai pihak maka tidak mungkin pembangunan desa dapat berjalan dengan baik. Oleh karena itu, komunikasi dan koordinasi memiliki peran penting guna membantu kepala desa dalam mengajak masyarakat guna berpartisipasi dalam pelaksanaan program-program pembangunan desa harus lebih diprioritaskan dan tepat sasarannya. Pembangunan yang dilakukan tentunya membutuhkan dukungan masyarakat maupun komunikasi sebagai modal utama dalam keberlangsungan suatu pembangunan desa.Pembangunan desa dapat dilaksanakan dengan baik, namun perlu ditunjang dengan baik maupun kesiapan sumber daya manusia aparatur pemerintah desa. Berdasarkan hasil wawancara dengan Sekretaris Desa dikatakan bahwa pelaksanaan pembangunan desa membutuhkan sumber daya aparatur yang mampu bisa bekerjasama baik dalam pemerintahan desa maupun dengan masyarakat desa sehingga program-program yang dilaksanakan dapat berjalan dengan baik. oleh karena itu, kemampuan sumber daya aparatur desa menjadi penting serta mampu berkomunikasi dengan masyarakat guna menunjang kegiatan-kegiatan pembangunan di desa.

Implementasi tugas kepala desa dalam pembangunan yang dilaksanakan di Desa Binjai Hilir dapat dilihat dari berbagai program pembangunan yang dilaksanakan. Menurut hasil wawancara dengan Kepala Desa dikatakan bahwa pelaksanaan program pembangunan di desa ada yang berbentuk fisik dan non fisik. Pembangunan fisik yang dilaksanakan seperti pembangunan jalan desa dan dusun, renovasi kantor desa, renovasi 
gedung sekolah TK, dan renovasi gedung puskesmas.Sementara yang berbentuk non fisik seperti pembinaan masyarakat dalam hal partisipasi, sosialisasi kesehatan tentang desa sehat maupun ibu dan anak, pembinaan ibu-ibu PKK mengenai kelompok usaha kreatif UKM. Semuanya diharapkan bisa dilaksanakan guna memberikan akses terhadap kebutuhan masyarakat maupun pelayanan publik kepada masyarakat.

Pembangunan desa dapat dilaksanakan dengan baik, namun perlu ditunjang komunikasi dengan baik maupun kesiapan sumber daya manusia aparatur pemerintah desa. Tuntutan profesionalitas aparatur pemerintahan desa saat ini tentunya harus disiapkan dengan baik serta memiliki kemampuan pelaksanaan tugas, komitmen terhadap kualitas kerja, dan dedikasi terhadap kepentingan masyarakat sebagai pihak yang dilayani oleh pemerintah desa. Oleh karena itu, koordinasi sangat penting dilakukan antara Kepala Desa dan pihak-pihak yang berkepentingan dalam memajukan pembangunan desa.

Implementasi tugas kepala desa berkaitan dengan perencanaan pembangunan desa. Hal ini tentunya membutuhkan sumber daya aparatur desa yang mampu merencanakan dengan baik. Sebagaimana hasil wawancara dengan Kepala desa yang mengatakan bahwa sumber daya aparatur perangkat desa maupun BPD secara kualitas pendidikan masih kurang, namun BPD dan pemerintah desa berupaya untuk tetap bekerja sebaik mungkin terutama dalam pelaksanaan program-program pembangunan desa. Sementara hasil wawancara dengan Kepala Desa dikatakan bahwa dari jumlah aparatur pemerintahan desa Binjai Hilir dari aspek tingkat pendidikan rata-rata tamatan SMU, diantaranya enam orang tamatan SMA atau sederajat dan satu orang tamatan SMP. Keterlibatan aktif aparatur desa sangat maksimal dalam pelaksanaan program-program pembangunan desa. Pemberdayaan terhadap aparatur terus dilakukan melalui pendidikan dan pelatihan melalui kerjasama dengan pihak kecamatan maupun kabupaten dalam rangka memberikan pemahaman dan pengetahuan yang diharapkan sehingga akan menghasilkan kualitas aparatur desa yang mampu bekerja dengan baik.

Perencanaan pembangunan desa disusun berdasarkan aspirasi masyarakat desa melalui BPD yang disampaikan kepada pemerintahan desa yang diharapkan untuk menggali potensi-potensi masyarakat desa.Berdasarkan hasil wawancara dengan Tokoh adat Binjai Hilir dikatakan bahwa pelaksanaan pembangunan desa membutuhkan keterlibatan aktif masyarakat yang secara bersama-sama melaksanakan pembangunan desa serta koordinasi yang intens dari berbagai pihak dalam pembangunan desa. Kedua hal ini sangat penting dalam kemajuan pembangunan desa serta sebagai penghambat dalam pelaksanaan pembangunan desa. Memajukan pembangunan desa tidak semudah yang dipikirkan karena ada faktor yang menjadi kendala dalam pembangunan itu sendiri, yang menjadi kendala dalam pelaksanaan pembangunan Desa Binjai Hilir misalnya partisipasi masyarakat yang masih kurang maupun koordinasi yang belum maksimal pada tingkatan pemerintahan desa dengan BPD serta pihak-pihak desa yang lainnya (tokoh masyarakat/ adat) sehingga hal ini menjadi penghambat dalam program pembangunan desa kedepan.

Partisipasi masyarakat merupakan proses yang dilakukan untuk memperkuat serta bagaimana meningkatkan kesadaran masyarakat agar turut pro aktif dalam kegiatan-kegiatan pembangunan. Pembinaan partisipasi sangat diperlukan sebagai tujuan utama dalam membina perilaku sosial masyarakat desa bahwa partisipasi memiliki arti penting guna membangun pembangunan desa dengan berlandaskan pada nilai-nilai partisipatif maupun nilai kebersamaan. Partisipasi merupakan keikutsertaan masyarakat dalam pelaksanaan suatu kegiatan dimulai dari tingkat paling awal yaitu perencanaan hingga kegiatan tersebut selesai dan pemanfaatannya dirasakan bersama-sama oleh masyarakat. Menurut hasil wawancara dengan Ketua BPD desa Binjai Hilir dikatakan bahwa partisipasi sendiri tidak terbatas pada kegiatan fisik atau pemberian dana namun juga menjaga mengelola dan mempertahankan apa yang sudah 
masyarakat capai dari suatu kegiatan yang diselenggarakan. Pembangunan bukan berarti peningkatan pendapatan masyarakat saja namun pembangunan merupakan suatu proses reorganisasi dan pembaharuan seluruh sistem serta aktivitas dalam hal ekonomi dan sosial dengan tujuan mensejahterakan kehidupan masyarakat.

Pembinaan partisipasi masyarakat berkaitan dengan beberapa aspek yang dilaksanakan seperti sosial budaya, pendidikan, ekonomi maupun kesehatan. Hal ini dimaksudkan agar ada kesadaran dari masyarakat bahwa partisipasi memiliki tujuan untuk bersama-sama membangun pembangunan desa yang lebih baik.Sementara hasil wawancara dengan Kaur pembangunan dikatakan bahwa pemerintahandesa dalam melaksanakan pembinaan terhadap masyarakat dengan cara mengumpulkan masyarakat untuk memberikan pengertian tentang apa-apa yang perlu dilaksanakan suatu kegiatan dan bagaimana pelaksanaannya nanti di lapangan. Apabila masyarakat telah memahami dan mengerti tentang hal tersebut maka pemerintah desa tinggal mengarahkan dan memberikan bimbingan bagaimana sistem pengelolaan suatu program baik program pemberdayaan masyarakat di bidang pendidikan, kesehatan, sosial budaya dan ekonomi. Pembinaan partisipasi dilakukan bukan hanya pada partisipasi masyarakat dalam pembangunan fisik saja, namun pemerintah desa juga perhatian kepada organisasi-organisasi sosial di desa seperti, PKK, lembaga adat, lembaga agama, dan karangtaruna. Hal ini dilakukan agar ada kesadaran dari masyarakat terhadap pentingnya organisasi sosial desa yang mendukung partisipasi masyarakat dalam pembangunan. Sementara dalam bidang sosial budaya pemerintahan desa lebih mengarahkan dalam peningkatan partisipasi masyarakat dalam program pembangunan harus seiring dan secara bersama-sama bergotong royong sehingga benar-benar pembangunan desa yang dilaksanakan mampu meningkatkan kesejahteraan masyarakat desa.

Kesadaran partisipasi masih kurang, namun pemerintahan desa tetap melakukan berbagai strategi dan pendekatan-pendekatan pembinaan dengan sosialisasi dan penyuluhan terkait program-program pembangunan desa kepada masyarakat. Dengan adanya strategi dan pendekatan seperti sosialisasi serta penyuluhan ini maka akan meningkatkan kebersamaan dalam membangun desa yang lebih baik. Oleh karena itu, pembinaan partisipasi dilakukan untuk mencegah timbulnya sikap-sikap apatis yang dapat menghambat pelaksanaan pembangunan desa. Implementasi tugas kepala desa berdasarkan Undang-Undang Desa sebagai acuan dalam pelaksanaan pembangunan di Desa Binjai Hilir. Dengan demikian, maka tugas kepala desa Binjai Hilir dapat dilaksanakan apabila di tunjang dengan beberapa faktor yang bisa mendukung dan sekaligus bisa menjadi penghambat, yakni komunikasi, pemberdayaan dan partisipasi masyarakat dalam pembangunan. Dengan demikian implementasi tugas kepala desa tentunya berperan penting dalam pembangunan desa yang secara esensial harus memiliki visi dan misi yang jelas dalam rangka mengelola dan melaksanakan pembangunan desa yang lebih efektif dan efisien, serta demokratis yang menempatkan masyarakat sebagai pelaku utama pembangunan.Partisipasi yang baik akan menghasilkan pembangunan yang berkelanjutan dengan didasarkan atas komitmen, keserasian dari masyarakat sehingga sebagai modal dalam percepatan pembangunan desa yang berkelanjutan, maju, mandiri dan sejahtera.

\section{KESIMPULAN DAN SARAN}

Berdasarkan hasil penelitian dan pembahasan yang dilakukan oleh peneliti dapat diperoleh kesimpulan bahwa dengan diterbitkannya Undang-Undang Nomor 6 tahun 2014 tentang Desa maka pelaksanaan tugas kepala desa Binjai Hilir dalam pembangunansudah dilaksanakan sesuai dengan kewenangan yang diberikan kepada kepala desa. Namundalam pelaksanaan tugas kepala desa, ada beberapa faktor yang menjadi penghambat seperti komunikasi yang belum maksimal dilaksanakan dengan lembaga desa, BPD dan masyarakat serta masih kurangnya kesadaran masyarakat dalam partisipasi pembangunan desa. Sedangkan yang menjadi faktor penunjang adalah 
keterlibatan aktif aparatur desa dalam pelaksanaan program-program pembangunan desa.

Berdasarkan kesimpulan di atas, maka peneliti menyarankan bahwa dengan adanya Undang-Undang Nomor 6 Tahun 2014tentang Desa ini diharapkan menjadi acuan dasar dalam pelaksanaan tugas dan fungsi kepala desa dalam

\section{DAFTAR PUSTAKA}

Marbun, 2000. Proses Pembangunan Desa, Menyongsong Tahun 2000. Surabaya: Erlangga

Nasution, 2001. Komunikasi Pembangunan Pengenalan Teori dan Penerapannya. Jakarta:RajaGrafindo Persada.

Slamet, M. 2003. Membentuk Pola Perilaku Manusia Pembangunan. Bogor: IPB Press.

Sanapiah Faisal, 2008. Format-Format Penelitian Sosial. Jakarta :Rajawali Press.

Sugiyono, 2008. Metode Penelitian Kuantitatif, Kualitatif, dan $R \& D$. Bandung : Alfabeta. menyelenggarakan pemerintahan, pemberdayaan masyarakat, dan melaksanakan pembangunan desa. Dengan demikian, tugas kepala desa akan penting jika pembangunan desa dilaksanakan dengan semangat kekeluargaan, gotong royong dan musyawarah.

Tjokroamidjojo. 1998. Pengantar Administrasi Pembangunan. Jakarta: LP3ES.

Widodo, Joko, 2006. Analisis Kebijakan Publik, Konsep dan Aplikasi Analisis Proses Kebijakan Publik. Bayumedia Publishing. Malang.

Winarno, Budi, 2004. Teori dan Proses Kebijakan Publik. Media Pressindo. Yogyakarta.

\section{$\underline{\text { Peraturan Perundang-Undangan }}$}

Undang-Undang Nomor 6 Tahun 2014 Tentang Desa.

Peratutan Pemerintah Nomor 43 Tahun 2014

Tentang Peraturan Peaksanaan Undang-Undang

Nomor 6 Tahun 2014 Tentang Desa. 